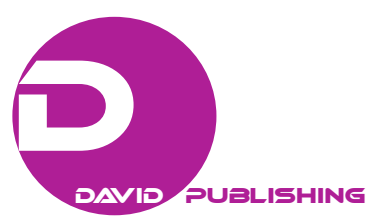

\title{
Translation of Chinese Opera Proverbs From the Perspective of Intertexuality Theory
}

\author{
ZHANG Li-li \\ Zhejiang Vocational Academy of Art, Hangzhou, China
}

\begin{abstract}
Due to China's ever-expanding opening-up, sustained rapid economic growth, and its rising international status, the sharp rise in demand of national consciousness has outstripped the original operation model. Chinese renaissance can not only be understood as a catalyst for globalization, but it does also enlarge the global village by opening new economic, political, diplomatic, intellectual, and artistic horizons. Our government pays more attention to publicize and preserve traditional culture. Therefore, it becomes an urgent task about how to do research and mining, preserve fine traditional Chinese culture, and enhance the international cultural communication. Rhymed opera proverb as an important part of Chinese opera culture mirrors the ideology and culture in China. The opera proverb is responsible for both inheriting the tradition and developing the ancient art. The biggest challenge is translation which is carrier of culture. Through good translation, we will gain a better understanding of the quintessence of our tradition and of the living embodiment of China and Chinese culture. This paper is intended to study opera proverb translation from the viewpoint of "intertextuality". The author believes that translation is a type of transforming activity intertextualized with language, text, and culture. Intertextuality theory is applied to investigate the process of translation. Intertextuality will be of great help to the translation of opera proverbs, which means not only to explore and transfer the literal meaning of the source text, but also to interpret and expound the cultural meaning. Only if a translation is reliable and makes sense of traditional culture can our culture be known and appreciated by the world.
\end{abstract}

Keywords: intertextuality, rhymed opera proverb, culture

\section{Introduction}

A series of initiatives of Chinese culture going out and promotion of Chinese culture to the world enhance us to accelerate the process of translation of publicity materials. Against the strength of China's economic globalization, cultural awareness follows and cultural confidence arises from a spiritual level. That means our culture is eager to understand and to be understood by other countries. In that case, our cultural values need to be fully appreciated and understood. This is an important part of our cultural development goal, so higher expectation is attached to translation of publicity materials.

As an important part of traditional Chinese culture, Chinese opera is a collection of Chinese ideology, culture, and art. The rhymed opera proverb is the opera artists' tactic saying of popular spoken language, which was accumulated and savvied from their daily practice. Acting skills and techniques are mingled and summarized as a jingle in order to communicate easily in practice. The Chinese opera proverb becomes popular

ZHANG Li-li, Lecturer, Zhejiang Vocational Academy of Art. 
as a special art form which conveys various information, simple and catchy, brief and philosophical, it is a guideline of artistic practice and unique treasure of national heritage as well. The opera proverb itself exists as part of the Chinese opera theory system. The rhymed Opera proverb in its form of proverb reflects and records opera ideology, opera practice, methods and techniques of ethnic performing. It explores and understands theories and principles of aesthetics of the ancient stage art. That is, the opera proverb with profound artistic conception and rich cultural connotations has historical value. So how to promote and extend the global influence of Chinese culture seems very urgent.

Intertextual translation has been applied to study the function of intertextual references in the translating process. According to Hatim and Mason, "intertextuality provides an ideal testing ground for basic semantic notions in practical pursuits such as translating and interpreting” (2001, p. 107). Venuti (2009) claimed that intertextuality is of great significance for both translators and receptor audience.

\section{Development of Intertextuality Theory}

Intertextuality was coined as a term by French critic Kristeva in the 1960s. During 1966 to 1968, Julia Kristeva gave birth to the concept of a new synthetic word "intertextuality" by combining and defining it in a broad way in her three essays : "Word, Dialogue and Novel”, "The Bounded Text", and "Structural Problem of the Text". Kristeva claimed that "each word (text) is the intersection of words (texts), where at least one other word (text) can be re-read, updated, concentrated, transformed and deepened” (1980, p. 66). In a sense, the value of a text consists in the integration and destruction of other texts. Further explanation is given: "Any text is constructed of a mosaic of quotations; any text is the absorption and transformation of another" in her Semiotic, Semantic Analysis (Samoyault, 2003). As a classic definition of intertextuality, it is always quoted. A text and other texts have several levels connection from words, phrases, clauses, sub-clauses to texts, discourses, and genres. Hatim and Mason (2001) have a classification study, according to which intertextuality can be founded on the interrelation between other texts, such as formulistic expressions, idioms and so on. These texts are manifest intertextuality and the next level is represented by the explicitly marked intertextuality relations of one text to other texts (Fairclough, 1992). In addition, constitutive intertextuality refers to the relationship between various genres and types conventions in a given text, which configurates similar genres and topics in the process of building a text.

There is intertextuality activity between translation of the same source text and target language in the other texts. The translation process itself is a distinctive spiritual activity of intertextuality, which contains intertextual relationships not only between source language and target language, translator and author, source language readers and target language readers, source language and target language text and the source language culture and the target culture in a broad sense (Neubert \& Shreve, 1992), but also in creating a much more prosperous meaning to the text it compares to as a technical copy or duplicate. The theory of intertextuality emphasizes the interactional reference between texts, which helps us recognize the relationship between the translation of source text and target text from a new perspective. According to the theory, the reference between source language and target language is mutual and they are in a relationship of intertextuality. Meaning can only be produced in the translation through referent texts. The source meaning of the text can be manifested after translation. That is why intertextuality requires translators to have higher cultural competence.

In foreign countries, the first applied intertextuality theory to translation studies is the one by Hatim and Mason (Hatim \& Mason, 1997). 
In their book Discourse and the Translator, intertextual translation theory is discussed from three aspects: three dimensions of context, intertextual references, and intertextual space. In our country, those who did earlier research concerning intertextuality are YANG Yan-song who issued "Intertextuality and Translation" in Chinese Translators Journal (1994) and four years later JIANG Xiao-hua who published research under a similar title "Intertextuality and Cultural Translation" in the same journal. ZHAO jing delivered a paper with the same title "Intertextuality and Translation" in Shangdong Foreign Language Teaching. Additionally, XIN Bin is an important scholar who extended research in an area of discourse analysis, his representative paper is “Pragmatic analysis of Discourse Intertexual Foreign Language Research” (2000).

All in all, although the theory of intertextuality originated in the 1960s, it still has a strong influence. The notion of intertextuality has presented itself in the field of translation which provides a new perspective. Intertextuality serves as a new approach to translation studies. There is an inherent interrelation between intertextuality and translation, which is mainly reflected in the knowledge that is of great help for a translator's work. Furthermore, intertextuality awakens the reader's attention to specific function of translators and readers in the process of translation. Intertextuality denies the ultimate meaning of the text, emphasizes fluidity of semantics, which can be interpreted as the phenomenon of a work with many different translation copies and continuous retranslation. Intertextuality focuses on the dynamic process of translation. Until 2012, researches on intertextuality in their homeland and abroad are still very active, some notions also being applied to the study of opera translation. With the help of intertextuality theory, opera proverb translation enhances the understanding of the Chinese culture through these proverbs, it strengthens the cultural exchange and cooperation between China and other countries, it deepens friendly relationships with other nations, promote the development of multi-culturalism.

\section{Translation of Opera Proverb and Its Cultural Connotation}

Historian Christopher Dawson (1889-1970) already indicated, in The Making of Europe, after the first tragedy of the 20th century the direction to follow: "If a true world-civilization is ever to be created, it will not be by ignoring the existence of the great historic traditions of culture, but rather by an increase of mutual comprehension” (1932). The significance of rhymed opera proverb translation is expressed by Mr. JI Xian-lin: "Chinese culture keeps vigorous relying on translation" (1995). With the continuous development of the human society, with the strengthening and deepening of the cultural contact, language communication is bound to occur. As Nida stated "translation is communication” (1993, p. 87), one of the translation's tasks is to achieve cultural exchanges. The translation of opera proverb has its specific character. Opera is part of culture and it is a performing language art. On other hand, language is an important carrier of culture and has a deep culture accumulation. The translation of opera proverb is not a transformation of different languages but it is a recreation of art and an activity of intercultural communication.

Opera translation is not a process of sole translation, but of expounding cultural connotation behavior. Classical Chinese opera proverbs record opera ideology, practical processes, skills, and techniques which have profound artistic conception and rich cultural connotations, so studying opera proverb has great historical value. As a whole, the research on classical Chinese opera translation is still relatively weak in our country. What the translator has to do is not only to explore and transfer the literal meaning of the source text, but also to correctly interpret and expound the cultural meaning, during which the knowledge of intertextuality will be of great help to the translator. The intersection between the source text and the target text helps us to interpret and make 
translation more faithful, moving towards equivalence. Now a lot of studies have been done in the domain of application of intertexuality to translation, of taking advantage of theoretical guidelines. Opera proverb translation will tend to do in a way that is more nuanced and deep.

\section{Principles and Approaches to Intertextual Translation}

To the Chinese people, the opera is more than just a musical. It is an experience that fuses folk songs, dances, poetry recitals, acrobatics, martial arts, and distinctive dialectical music. It is one of the world's oldest continuously practiced performing arts that also never stops evolving. Intertextual translation lags behind in the field of opera translation and practice in our country. Many researchers pay more attention to the reasonable refinement of traditional experience, while ignoring the development of translation practice. Under the background of pursuing speedy and beneficial translation, translators lack patience, few of them check the translation word by word, sentence by sentence, which results in amount of defective works. Opera translation is a process of complexity and particularity-the practical process of translation requires translators to be like writers, readers and audiences, to thoroughly consider the full, three-dimension range. Only a comprehensive and objective understanding of opera translation can promote the continuous development of practical translation.

We take opera proverb translation from two aspects.

\section{Literal Level}

The intertextual text is manifest and obvious. It can be quoted directly, implicated or directed by some surface characteristics such as quotation marks. There is intertextual reference between texts; it can be found in one text or even in the same paragraph. So in the process of translation, if a translator can make use of intertextuality theory to interpret the intertextual phenomenon in the source text-which can not only deepen the understanding of the source language, as well as help to organize the constitutive translation of the target language. Commonly, there are two ways in the translation practice.

Adding notes to translation. For example:

Tongzi Kung Fu-Kung Fu that acquired at very early age.

“Tongzi Gong” refers to disciplined training from a very young age to be able to naturally achieve the singing and reciting style. In China, Tongzi related to Chinese traditional medical term Yuan Jing, which refers to childhood. "Tongzi Gong” means those who acquire dance and acrobatic skills in childhood. In fact, "Tongzi Gong" has been expanded to not only refer to the martial arts, but also build good foundations for everything. How to give "Tongzi” a good translation? Literally, it means "young boy”, but "Tongzi Gong” has not been defined as boy or girl, so "young boy" is not good idea for "TongZi Gong”. We may try to translate literarily "childhood as Kung Fu” or to add notes "Tongzi KungFu—Kung Fu that acquired at very early age”.

Manifest the containing. For example:

Singing opera needs good throat, taking a bow needs strong arms.

Three years for arms, five year for legs, twenty years for opera singing.

In these opera proverbs, throat, arms, three years, five years, twenty years illustrate the idea that Chinese opera needs comprehensive qualities, long time and hardworking to master.

Liberal: It's a life-long process. It never stops. 


\section{Cultural Level}

Intertextuality seems indirect and vague from cultural aspect. Generally, the intertextual text exceeds the limited text, which combines with ethnical language and culture, including customs, religion, literature, traditions, political systems together to express rich cultural connotation of metaphor, literary quotation, and image. We can find examples in Chinese opera, in its distinctive features.

Space and imagination. In Chinese opera one table and two chairs, are props unique to opera and give the audience more room for imagination.

Opera proverb goes:

World itself is a big stage, stage represents a small world.

Two or three steps represent miles away. Three to five persons stand for millions of soldier.

Formulation and comprehension. Opera is a form of traditional Chinese theatre art that combines music, oval performance (Chang), recitation (Nian), acting and mime (Zuo), dance and acrobatics (Da); these are four distinctive formulated features. In Chinese opera, we need complete ease, eye movements, hand gestures, and gait that express the thoughts and emotions of the opera characters. Teachers have to teach one by one, hand by hand, word by word, sentence by sentence, So Chinese opera emphasizes “Tongzi Gong”, disciplined training from a very young age to be able to naturally achieve the singing and reciting skills, stressing "one minute on stage, ten years to practice".

Literal: one minute of performance on stage, ten years of hard work off stage.

Liberal: Practice makes perfect./Rome was not built in a day.

Synthetic: One minute of brilliant performance on stage, the years of hard work off stage.

Synthesis. WANG Guo-wei's (Chinese opera theorist) classic definition of Chinese opera, which is always quoted, claimed that the opera tells a story through singing and dance performance (2006). Opera basic skills include dance movements and special acrobatic movements while singing or reciting, necessary requirements to be mastered by all actors and actresses. As a proverb goes:

Opera actors are not afraid of Three Death.

Three Death refers to Hua Lian (painted-face male role) dare not hot to death, Tsing Yi (usually a faithful wife, lover or maiden in distress) dare not freeze to death, Wu Dan (female warrior) dare not tire to death. In Chinese opera cultural, facial make-up with a variety of colors and patterns outline is applied to the male roles of Jing and Chou (Da Hua Lian), with particular styles to symbolize the different personalities, characteristics, and fates of the roles. In addition to the painted face, they have to wear heavy underwear to make the body look giant. The actors in the role of Tsing Yi, regardless of whether it is summer or winter, have to wear a single pair of pants, covered with a thin cloak. (Opera costumes are mainly made of satin, crepe, and silk.) Those in the role of Wu Dan have to do a lot of actions. Jing bears colored facial makeup to express inner-heart world. Tsing Yi emphasizes singing usually by standing still, especially in frozen winter, the actors have to stand still and face against the cold wind (Chinese opera was performed mostly on stage, in the open air, teahouses, or temple courtyards). So regardless of the cold of winter, Tsing Yi still has to wear thin cloth; regardless of hot summer, Hua Lian has to wear heavy cloth. Wu Dan has to keep moving, to run in circles around the stage. With this background knowledge, we can say:

Hualian endures hot, Qinyi bears cold and Wudan suffers weary.

We should use "endure, bear, suffer" to represent the three "death", which implies the disciplined training 
with complete ease, eye movements, hand gestures, and gait that express the thoughts and emotions of the opera characters. As the opera proverb goes, "Singers would rather wear a worn and torn costume than one that did not correctly represent the character he was portraying”. Opera proverbs contain rich cultural connotations, namely, you can learn from these proverbs a great deal about Chinese traditions and core values, such as being filial to parents, loyalty, benevolence, and uprightness. Just as one opera proverb goes "No matter how perfect technique you acquire, you still can’t be a true man without learning moral” which focuses on the importance of behaving yourself through learning morals when you practice skills and techniques. Therefore, the correct interpretation of the original text can be translated into: "Moral plays a higher role than the acting technique".

\section{Difficulties in Translating Opera Proverb}

\section{Material Collection}

Historically, a lot of Chinese opera proverbs are top secret. As the saying goes "I would rather give you a field than tell you the way". To collect these proverbs, we need a long time. These experienced concise proverbs belong to the artists themselves, those in the outside world know nothing about it. We only get this knowledge mainly from their life experience and performance, so these precious treasures are few left. For the opera proverb translation, we have to attach more importance to collection and organization, in addition to guiding ideology, updating research methods and tools.

\section{Dynamic Process of Translation}

For translating opera, the translator needs not only good foreign language skills, but good knowledge about opera and awareness of cultural communication. The opera proverb is responsible for both inheriting the tradition and developing the ancient art. So we have to strengthen the language storage, the understanding and perception of intertextuality, and the correspondence of intertextuality awareness in our daily life. Thus it can be said: In intertextual translating activity, the more active we are between source text and target text, the more aware we are of the correspondence between target and source, and vice versa. Intertextuality inspires readers' attention to translation studies and prompts them to review the role of readers and translators in the process of translation. Intertextuality emphasizes the text as a dynamic process instead of accepting an ultimate meaning. All of which can effectively explain in the field of translation the phenomenon of constant retranslation. Intertextuality reinforces the dynamic process of the text, and it also inspires us to pay attention to the formation of translation.

\section{Conclusion}

The Chinese opera crystallizes the history, culture, customs, philosophy, and humanistic thought of China. With its translation, it helps more people to sample Chinese culture, understand Chinese philosophy and ways of thinking, and appreciate the charm of Chinese traditions, thus making the Chinese culture more attractive.

The opera rhymed proverb is the life-long experience of people which contains rich cultural connotations, conventions, and wisdom. It is the recognition and awareness of people's life and world, the summarizing of the aesthetic spirit and the aesthetic pursuit of the opera. Moreover, opera proverbs can use popular and spoken opera language such as "Singing White Face" (wear the white makeup of stage villain); "Singing Contrary Keynote" (deliberately speak or act contrary to); "Setting the Tune" (make route you have to follow); all of these proverbs are not only part of our spoken daily language, but they also deepen the life experience and enrich the daily language. These languages also carry the responsibility of preserving Chinese opera heritage. 
The good translation of opera proverbs can reflect cultural connotations of the opera. So how to translate faithfully, equivalent to the target language, how to combine opera translation with intertextuality, how to deepen thinking and understanding of source text and target text, how to weave intertextual information about characters and tales in the text, how to achieve the fullness of opera proverb translation, all of these aims enhance us to go further in future studies.

\section{References}

9th Euro-China Forum. (June 27-28 2011). Paris: UNESCO. Retrieved from http://www.ceibs.edu/ase/ecforum/about.htm Christopher, D. (1932). The making of Europe: An introduction to the history of European Unity. London: Sheed and Ward. Fairclough, N. (1992). Discourse and social change. Cambridge: Polity Press.

Hatim, B., \& Mason, I. (2001). Discourse and the translator. Shanghai: Shanghai Foreign Language Education Press.

JI, X. L (1995). 《中国翻译词典》序 (Prologue of A Companion for Chinese Translator). 中国翻译, (6), 2-3.

JIANG, X. H. (1998). 互文性与文学翻译 (Intertextuality and cultural translation). 中国翻译, (2), 20-25.

Kristeva, J. (1980). Word, dialogue and novel. In L. S. Roudiez (Ed.), T. Gora et al. (Trans.), Desire in language: A semiotic approach to literature and art (pp. 64-91). New York: Columbia University Press.

Neuber, A., \& Shreve, G. M. (1992). Translation as text. Kent: The Kent University Press.

Nida, E. A. (1993). Language, culture and translating. Shanghai: Shanghai Foreign Language Education Press.

Samoyault, T. (1st January 2003). 互文性研究 (The study of intertextuality) (W. SHAO, Trans.). Tianjin: 天津人民出版社.

Venuti, L. (2009). Translation, intertextuality, interpretation. Romance Studies, 27(3), 157-173.

WANG, G. W. (2006). 宋元戏曲史 (Opera history of Song and Yuan dynasty). Beijing: 中国书籍出版社.

XIN, B. (2000). 语篇幅互文性的语用分析 (Pragmatic analysis of discourse intertexual). 外语研究, (3), 14-16.

YANG, Y. S. (1994). 互文性与翻译 (Intertextuality and translation). 中国翻译, (4), 10-12.

ZHAO, J. (1994). 互文性与翻译 (Intertextuality and translation). 山东外语教学, (4), 39-42. 